\title{
KEBIJAKAN DELIBERATIF SEBAGAI DIMENSI-DIMENSI UTAMA DALAM PENYUSUNAN KEBIJAKAN PUBLIK YANG UNGGUL.
}

\author{
Muh. Yusril Nurdin \\ Prodi Administrasi Publik. Fakultas Ilmu Sosial Dan Politik \\ Universitas Muhammadiyah Sidenreng Rappang \\ Email : Muhammadyusrilnurdin11@gmail.com
}

\begin{abstract}
ABSTRAK
Penelitian ini bertujuan untuk mengetahui kebijakan deliberatif sebagai dimensi utama dalam penyusunan kebijakan publik yang unggul. Kebijakan sebagai serangkaian tindakan yang diusulkan seseorang, kelompok atau pemerintah dalam suatu lingkungan tertentu dengan menunjukkan hambatan-hambatan dan kesempatan-kesempatan terhadap pelaksanaan usulan kebijakan tersebut dalam rangka mencapai tujuan tertentu. Kebijakan deliberatif merupakan bentuk derivasi dari demokrasi deliberatif. Teori dan proses kebijakan publik memiliki definisi yang tidak hanya menekankan pada hal-hal yang diusulkan pemerintah, tetapi juga mencakup arah tindakan yang dilakukan oleh pemerintah. Proses kebijakan terdiri dari : perumusan kebijakan, implementasi kebijakan, monitoring kebijakan, dan evaluasi kebijakan. Analisis kebijakan adalah penerapan metode dan teknik analisis yang bersifat multidisiplin dalam proses kebijakan analisis kebijakan memberikan landasan untuk membedakan tiga bentuk utama analisis kebijakan, antara lain; analisis kebijakan prospektif, analisis kebijakan restrospektif, dan analisis kebijakan terintegrasi.
\end{abstract}

Kata kunci : deliberatif, dimensi, kebijakan. 


\section{PENDAHULUAN}

Menurut kamus Cambride, kebijakan publik adalah kebijakan pemerintah yang memengaruhi setiap orang di suatu negara atau negara bagian atau kebijakan secara umum. David Easton dalam A Systems Analysis of Political Life (19) mendefinisikan kebijakan publik sebagai pengalokasian nilai-nilai secara paksa kepada seluruh anggota masyarakat. Tujuan kebijakan publik adalah dapat dicapainya kesejahteraan masyarakat melalui peraturan yang dibuat oleh pemerintah.

Salah satu persoalan yang mengemuka ketika berbicara tentang kebijakan publik adalah dimana posisi publik dalam proses perumusan tersebut. Gamblangnya, ketika berbicara publik, dimana keterlibatan atau peran publik dalam penentuan kebijakan tersebut.

Diskursus tentang partisipasi publik sendiri dalam proses perumusan, implementasi, evaluasi kebijakan mendapatkan tempat tatkala runtuhnya Orde Baru. Sebagaimana diketahui, ketika kebijakan model elitis yang menempatkan publik atau masyarakat umum hanya sekedar menjadi penonton pembangunan telah terbukti gagal menuju kebijakan publik yang unggul.

Kebijakan publik merupakan ilmu yang relatif baru karena secara historis baru muncul pada pertengahan dasawarsa 1960- an sebagai sebuah disiplin yang menonjol dalam lingkup administrasi publik maupun ilmu politik. Sementara itu, analisis kebijakan publik bisa dibilang telah lama eksis dan dapat dirunut sejak adanya peradaban umat manusia. Sejak itu, kebijakan publik tidak terpisahkan dari kehidupan manusia dalam bentuk tataran mikro individual maupun konteks tataran makro dalam kehidupan bermasyarakat dan bernegara (Wahab, 2008). Kebijakan publik merupakan keputusan-keputusan atau pilihan-pilihan tindakan yang secara langsung mengatur pengelolaan dan pendistribusian sumberdaya alam, finansial dan manusia demi kepentingan publik, yakni rakyat banyak, penduduk, masyarakat atau warga negara. Ditinjau dari proses, kebijakan publik diartikan sebagai hasil dari adanya sinergi, kompromi atau bahkan kompetisi antara berbagai gagasan, teori, ideologi, dan kepentingan-kepentingan yang mewakili sistem politik suatu negara. Oleh karena itu, kebijakan merupakan instrumen pemerintah untuk melakukan suatu tindakan dalam bidang tertentu seperti fasilitas umum, tranportasi, pendidikan, kesehatan, perumahan, kesehjahteraan, dan lain-lain yang dianggap akan membawa dampak positif bagi kehidupan warganya. Pengertian lainnya, kebijakan publik hanya sebatas dokumen- 
dokumen resmi seperti perundang-undangan, dan peraturan- peraturan pemerintah. Namun sebagian lagi mengartikan kebijakan publik sebagai pedoman acuan, strategi dan kerangka tindakan yang dipilih atau ditetapkan sebagai garis besar pemerintah dalam melakukan kegiatan pembangunan(Suharto, 2007).

Lahirnya Undang-Undang Nomor 23 Tahun 2014 tentang Pemerintahan Daerah membuat kebijakan tentang desa dalam memberi pelayanan, peningkatan peran serta dan pemberdayaan masyarakat desa yang ditujukan bagi kesejahteraan masyarakat. Otonomi daerah serta dalam era globalisasi, pemerintah daerah dituntut memberikan pelayanan yang lebih prima serta memberdayakan masyarakat sehingga masyarakat ikut terlibat dalam pembangunan untuk kemajuan daerahnya, karena masyarakatlah yang lebih tahu apa yang mereka butuhkan serta pembangunan yang dilakukan akan lebih efektif dan efisien dan dengan sendirinya masyarakat akan mempunyai rasa memiliki dan tanggungjawab(Mustanir et al., 2018).

\section{PENGERTIAN KEBIJAKAN}

Carl J. Friedrick (Suwitri, 2008) mengartikan kebijakan sebagai serangkaian tindakan yang diusulkan seseorang, kelompok atau pemerintah dalam suatu lingkungan tertentu dengan menunjukkan hambatan-hambatan dan kesempatan-kesempatan terhadap pelaksanaan usulan kebijakan tersebut dalam rangka mencapai tujuan tertentu.

Irfan Islamy telah mengumpulkan beberapa pengertian kebijakan publik seperti pendapat Thomas R. Dye, George C. Edwards dan Ira Sharkansky, James Anderson dan David Easton. Apabila diperhatikan dengan seksama terdapat beberapa sudut pandang dari para ilmuwan administrasi publik yang dapat diklasifikasikan sebagai berikut :

1. Kebijakan publik dipandang sebagai tindakan pemerintah.

2. Kebijakan publik dipandang sebagai pengalokasian nilai-nilai masyarakat yang dilakukan pemerintah.

3. Kebijakan publik dipandang sebagai rancangan program-program yang dikembangkan pemerintah untuk mencapai tujuan. 
Dari ketiga sudut pandang terhadap pengertian kebijakan publik, tampaklah bahwa kebijakan publik hanya dapat ditetapkan pemerintah, pihak-pihak lain atau yang lebih dikenal dengan sebutan aktor-aktor kebijakan publik hanya dapat mempengaruhi proses kebijakan publik dalam batas kewenangannya masing-masing.

\section{KEBIJAKAN DELIBERATIF}

Kebijakan deliberatif dapat dikatakan derivasi demokrasi deliberatif. Kebijakan deliberatif adalah kebijakan yang dirumuskan melalui proses pembahasan intensif antara pemerintah dan warga.krasi deliberatif berakar pada konsepsi "ruang publik" (public sphere) yang artinya cara pengambilan keputusan yang menekankan musyawarah dan penggalian masalah melalui dialog stakeholder. (Fitriana et al., 2020). (Kustriani, 2015) menyatakan bahwa demokrasi deliberatif adalah konsep demokrasi yang mendasarkan diri pada mekanisme musyawarah secara mendalam serta mengutamakan pengunaan cara-cara dialogis.Dalam logika demokrasi deliberatif sebagaimana dikembangkan Jurgen Habermas dalam (Setiawan, 2014), seluruh proses pengambilan kebijakan mesti didasarkan pada asas tindakan komunikatif. Kebijakan publik yang akan diimplementasikan harus mendapatkan dukungan dari publik, yang bisa digali dengan berbagai metode aspirasi, seperti dengar pendapat atau konsultasi publik, diskusi kelompok terfokus, musyawarah dan sebagainya. Selain itu, dapat diasumsikan bahwa keterlibatan publik yang lebih tinggi dalam proses pembentukan kebijakan, semakin tinggi rasa memiliki dan dukungan publik untuk kebijakan, sehingga mendorong penerapan dan penegakan kebijakan yang efektif.(Nur khofifah, 1967)

Good governance pada pencapaiannya wajib didukung sang public service menjadi orientasi pada penyelenggaraan pelayanan. Pelayanan publik sebagai bagian krusial pada pencapaian tujuan pemerintahan yang baik. Bahkan, pelayanan publik membutuhkan pelayanan

yang sama, tidak memiliki evaluasi yang negatif terhadap pelayanan yang diberikan. Menurut Safroni (2012), bahwa karakteristik-karakteristik pelayanan birokrasi yang berkualitas merupakan pelayanan yang bersifat anti birokrasi, distribusi pelayanan, dan desentralisasi dan berorientasi dalam klien, penekannya menggunakan cara: Pemerintah membangun suasana kompetitif dalam 
memberikan pelayanan; Pemerintah berorientasi pada kebutuhan pasar, bukan birokrasi; Pemerintahan desentralisasi dan lebih proaktif(Yenni Jamal, Ahmad Mustanir, 2020).

\section{DIMENSI KEBIJAKAN PUBLIK}

\section{Proses kebijakan}

Sifat kebijakan publik sebagai arah tindakan dapat dipahami secara lebih baik apabila konsep ini diperinci menjadi beberapa kategori, antara lain tuntutan kebijakan, keputusan kebijakan, pernyataan kebijakan, hasil kebijakan, dan dampak kebijakan. Dengan mengacu pada tahap-tahap kebijakan yang ditawarkan Jones dan beberapa ahli lainnya, domain kebijakan publik meliputi penyusunan agenda, formulasi kebijakan, adopsi kebijakan, implementasi, dan penilaian kebijakan.

Proses kebijakan publik merupakan proses yang rumit, yaitu:

1. Melibatkan percabangan yang luas. Yaitu berhubungan dengan keseluruhan sistem, perubahan pada satu aspek sosial akan berdampak pada keseluruhan sistem.

2. Melibatkan perspektif jangka panjang. Keputusan dalam proses kebijakan publik diharapkan bukan hanya berdampak positif pada jangka waktu yang pendek tetapi juga diharapkan sampai jangka waktu yang panjang.

3. Menggunakan sumber-sumber kritis untuk meraih kesempatan yang diterima dalam lingkungan yang berubah. Sumber daya manusia dan bukan manusia harus dikondisikan agar selalu dapat mendukung situasi dan lingkungan yang dinamis yang dihadapi proses kebijakan public.

4. Merupakan proses intelektual. Artinya tahap-tahap di dalam proses kebijakan publik membutuhkan pemikiran-pemikiran yang rasional.

5. Kelanjutan proses sosial yang dinamis. Proses kebijakan publik merupakan proses sosial yang dinamis dari implementasi hingga perbaikan dan penyesuaian kebijakan terhadap lingkungan 
yang berubah. Setiap perubahan sosial yang terjadi akan direspons oleh aktor kebijakan publik melalui perubahan kebijakan publik.(Suwitri, 2008).

S. Pradja (26: 2014) dalam menjelaskan pemimpin dan kepemimpinan, ada beberapa hal yang perlu di perhatikan, di antaranya: pertama, kekuasaan dan kewenangan, yaitu kemampuan untuk bertindak bagi seorang pemimpin untuk menggerakkan bawahannya agar mengikuti kehendaknya dalam mencapai tujuan yang telah di tentukan sebelumnya. Kedua, kewibawaan, yaitu berbagai keunggulan yang dimiliki seorang pemimpin, sehingga membedakan dengan yang di pimpinnya, dan dengan keunggulan tersebut, orang lain patuh dan bersedia melakukan kegiatankegiatan yang di kehendakinya. Ketiga, kemampuan, yaitu keseluruhan daya, baik berupa keterampilan sosial maupun keterampilan teknis yang melebihi orang lain(Mustanir \& Jaya, 2016).

\section{Analisis kebijakan}

Analisis kebijakan adalah penerapan metode dan teknik analisis yang bersifat multidisiplin dalam proses kebijakan. Menurut William N. Dunn (Subarsono, 2005), bahwa hubungan antara komponen-komponen informasi kebijakan dan metode-metode analisis kebijakan memberikan landasan untuk membedakan tiga bentuk utama analisis kebijakan, antara lain; analisis kebijakan prospektif, analisis kebijakan restrospektif, dan analisis kebijakan terintegrasi.

\section{a. Analisis Kebijakan Prospektif}

Analisis ini identik dengan produksi atau transformasi informasi sebelum aksi kebijakan dimulai dan diimplementasikan cenderung mencirikan cara beroperasi para ekonom, analisis sistem, dan peneliti operasi. Analisis prospektif seringkali menimbulkan jurang pemisah yang besar antara pemecahan masalah yang diunggulkan dan upaya-upaya pemerintah untuk memecahkan.

b. Analisis Kebijakan Retrospektif 
Analisis ini dalam banyak hal sesuai dengan deskripsi penelitian kebijakan, juga dijelaskan sebagai penciptaan dan transformasi informasi sesudah aksi kebijakan dilakukan.

c. Analisis Kebijakan yang Terintegrasi

Analisis ini merupakan bentuk analisis yang mengkombinasikan gaya operasi para praktisi yang menaruh perhatian pada penciptaan dan transformasi informasi sebelum dan sesudah tindakan kebijakan diambil. Analisis kebijakan yang terintegrasi tidak hanya mengharuskan para analis untuk mengkaitkan tahap penyelidikan retrospektif dan prospektif, tetapi juga menuntut para analis untuk terus menerus menghasilkan dan mentransformasikan informasi setiap saat.

Partispasi masyarakat merupakan suatu proses yangdapat mendukung masyarakat untuk mulai "sadar" akan situasi dan masalah yang dihadapinya serta berupaya mencari jalan keluar yangdapat dipakai untuk mengatasi masalah mereka (memiliki kesadaran kritis). Sumardi (2010:46), mengemukakan bahwa partisipasi adlah peran serta seseorang atau kelompok masyarakat dalam proses pembangunan baik dalam bentuk pernyataan maupun dalam bentuk kegiatan dengan memberi masukan pikiran, tenaga, waktu, keahlian, modal, dan atau materi, serta ikut memanfaatkan dan menikmati hasil-hasil pembangunan(Zhilviana Sulaeman, Ahmad Mustanir, 2019).

Sistem perencanaan pembangunan nasional Indonesia yang dengan pendekataan top top down dan Bottom up, nampaknya akan menjamin adanya keseimbangan antara prioritas nasional dengan aspirasi lokal dalam perencanaan pembangunan daerah. Namun yang terjadi banyak daerah belum sepenuhnya mengakomodasi aspirasi lokal, karena sebagian besar proposal yang diajukan berdasarkan aspirasi lokal telah tersingkir dalam rapat koordinasi yang menempatkan proposal yang diajukan tingkatan pemerintahan yang lebih tinggi tanpa memperhatikan proposal yang diajukan oleh tingkat pemerintahan dibawahnya. Akibatnya, proposal akhir yang masuk ke pusat biasanya di dominasi oleh program yang diajukan oleh level pemerintahan yang lebih tinggi(Mustanir \& Abadi, 2017) 
Perencanaan pembangunan suatu kumpulan kebijaksanaan dan program pembangunan untuk merangsang masyarakat dan swasta untuk menggunakan sumber daya yang tersedia secara lebih produktif. Arthur W. Lewis (2005). Perencanaan pembangunan adalah cara atau teknik untuk mencapai tujuan pembangunan secara tepat, terarah dan efisien sesuai dengan kondisi daerah yang bersangkutan. Sjafrizal (2014 : 24). Musrenbang(Mustanir \& Rusdi, 2018).

Keberhasilan implementasi kebijakan ditentukan oleh banyak faktor dan masing-masing faktor tersebut saling berhubungan satu sama lain. Untuk memperkaya pemahaman tentang berbagai faktor yang terkait dalam implementasi, maka pada bagian ini beberapa teori implementasi kebijakan dan dijadikan sebagai landasan pijak dalam penelitian ini(Mustanir \& Darmiah, 2016).

Sasaran pembangunan masyarakat adalah seluruh lapisan masyarakat yang heterogen, mereka memiliki karakter yang beragam pula. Oleh karenanya sebagai agen perubahan harus mampu memahami semua karakter klien, baik itu tingkat pendidikan, kondisi sosial ekonomi, budaya, bahasa, kepercayaan atau nilai-nilai yang diyakininya. Agen pembaharu harus mampu memilih berbagai kerakter masyarakat yang menghambat atau percepat perubahan yang kita harapkan. Pendekatan yang harus dilakukan kepada setiap golongan tersebut juga tidak sama, yang paling penting adalah bahwa pada akhirnya semua lapisan atau golongan masyarakat mau menerima dan melakukan perubahan demi perbaikan mutu hidupnya(Mustanir, Fitriani, et al., 2020).

This study was conducted by using descriptive explanatory research. It was a combination of descriptive research and explanatory research. Keith Punch [5], stated that A descriptive sets out to collect, organize and summarize information about the matter being studied while an explanatory study is on the other hand, sets out to explain and account for the descriptive information. Description is a more restricted purpose than explanation. Both of those researches were used to look for a comprehensive answer of the research questions in identifying and exploring Transect as the method in participatory development planning. This research used qualitative approach. Qualitative research is empirical research where the data are not in the form of number(Mustanir, Ali, et al., 2020). 
Di lingkup kelurahan harus terjadi pembangunan dan perubahan ke arah yang lebih baik. Hal tersebut dapat diwujudkan oleh Kepala Kelurahan secara terencana dan dapat dilakukan dengan adanya pemberdayaan masyarakat.Pemberdayaan masyarakat dapat dilakukan melalui partisipasi aktif masyarakat yang harus difasilitasi dengan adanya pelaku pemberdayaan masyarakat yang berasal dari seorang pemimpin(Mustanir et al., 2019).

\section{KESIMPULAN}

Kebijakan publik merupakan keputusan-keputusan atau pilihan-pilihan tindakan yang secara langsung mengatur pengelolaan dan pendistribusian sumberdaya alam, finansial dan manusia demi kepentingan publik, yakni rakyat banyak, penduduk, masyarakat atau warga negara. Ditinjau dari proses, kebijakan publik diartikan sebagai hasil dari adanya sinergi, kompromi atau bahkan kompetisi antara berbagai gagasan, teori, ideologi, dan kepentingankepentingan yang mewakili sistem politik suatu Negara, Kustriani, 2015) menyatakan bahwa demokrasi deliberatif adalah konsep demokrasi yang mendasarkan diri pada mekanisme musyawarah secara mendalam serta mengutamakan pengunaan cara-cara dialogis.Dalam logika demokrasi deliberatif sebagaimana dikembangkan Jurgen Habermas dalam (Setiawan, 2014), seluruh proses pengambilan kebijakan mesti didasarkan pada asas tindakan komunikatif. 


\section{REFERENSI}

Mustanir, A., \& Abadi, P. (2017). Partisipasi Masyarakat Dalam Musyawarah Rencana Pembangunan Di Kelurahan Kanyuara Kecamatan Watang Sidenreng Kabupaten Sidenreng Rappang. Jurnal Politik Profetik, 5(2), 247-261. http://journal.uinalauddin.ac.id/index.php/jpp/article/viewFile/4347/3986\%0Ahttp://journal.uinalauddin.ac.id/index.php/jpp/issue/view/636

Mustanir, A., Ali, A., Yasin, A., \& Budiman, B. (2020). Transect on Participatory Development Planning in Sidenreng Rappang Regency. 6(3), 250-254. https://doi.org/10.4108/eai.25-102019.2300523

Mustanir, A., \& Darmiah, D. (2016). Implementasi Kebijakan Dana Desa Dan Partisipasi Masyarakat Dalam Pembangunan Di Desa Teteaji Kecamatan Tellu Limpoe Kabupaten Sidenreng Rappang. Jurnal Politik Profetik, 4(2), 225-238. http://journal.uinalauddin.ac.id/index.php/jpp/article/view/2749\%0Ahttp://journal.uinalauddin.ac.id/index.php/jpp/issue/view/457

Mustanir, A., Fitriani, S., Adri, K., Nurnawati, A. A., \& Goso, G. (2020). Sinergitas Peran Pemerintah Desa dan Partisipasi Masyarakat Terhadap Perencanaan Pembangunan di Kabupaten Sidenreng Rappang (The Synergy of Village Government's Role and Community Participation in the Process of Development Planning in Sidenreng Rappang D. Journal of Government Science (GovSci), 2020, 1(2): 84-108, 2020(2), 84-108.

Mustanir, A., \& Jaya, I. (2016). Pengaruh Kepemimpinan Dan Budaya Politik Terhadap Perilaku Pemilih Towani Tolotang Di Kecamatan Maritengngae Kabupaten Sidenreng Rappang. Jurnal Politik Profetik, 4(1), 84-97. http://journal.uinalauddin.ac.id/index.php/jpp/article/view/2741\#\%0Ahttp:/journal.uinalauddin.ac.id/index.php/jpp/issue/view/430

Mustanir, A., Kamarudding, S., Akhwan, A., Madaling, \& Mutmainna. (2018). Peranan Aparatur Pemerintahan Desa dan Partisipasi Masyarakat Dalam Musyawarah Perencanaan Pembangunan di Desa Tonrongnge Kecamatan Baranti Kabupaten Sidenreng Rappang. Jurnal Ilmiah Clean Government, 2(Desember), 67-84. 
http://lonsuit.unismuhluwuk.ac.id/index.php/clean/article/view/213

Mustanir, A., \& Rusdi, M. (2018). Participatory Rural Appraisal (PRA) Sebagai Sarana Dakwah Muhammadiyah Pada Perencanaan Pembangunan di Kabupaten Sidenreng Rappang. Prosiding Konferensi Nasional Ke-8 Asosiasi Program Pascasarjana Perguruan Tinggi Muhammadiyah Aisyiyah (APPPTMA), 8(3 Des), 467-475. http://asosiasipascaptm.or.id/index.php/publikasi/prosiding-konferensi-nasional-appptma-ke $-8$

Mustanir, A., Samad, Z., Jabbar, A., Ibrahim, M., \& Juniati, J. (2019). Kepemimpinan Lurah Terhadap Pemberdayaan Masyarakat Di Kelurahan Lautang Benteng Kabupaten Sidenreng Rappang. Journal of Social Politics and Governance (JSPG), 1(2), 99-118. https://doi.org/10.24076/jspg.v1i2.185

Nur khofifah. (1967). KEBIJAKAN DELIBERATIF. Angewandte Chemie International Edition, 6(11), 951-952., 43182067, 5-24.

Subarsono, A. (2005). Analisis Kebijakan Publik : Konsep Teori Dan Aplikasi. Pustaka Pelajar, 2(9), 9 .

Suharto, E. (2007). Kebijakan Publik sebagai Kebijakan Publik. 2, 78-91.

Suwitri, S. (2008). Konsep Dasar Kebijakan Publik. Atmospheric Environment, 42(13), 2934-2947.

Yenni Jamal, Ahmad Mustanir, A. L. (2020). Penerapan Prinsip Good Governance Terhadap Aparatur Desa Dalam Pelayanan Publik Di Desa Ciro-Ciroe Kecamatan Watang Pulu Kabupaten Sidenreng Rappang. PRAJA: Jurnal Ilmiah Pemerintahan, 8(3), 207-212. https://doi.org/10.51817/prj.v8i3.298

Zhilviana Sulaeman, Ahmad Mustanir, A. I. M. (2019). Partisipasi Masyarakat Terhadap Perwujudan Good Governance Di Desa Damai Kecamatan Watang Sidenreng Kabupaten Sidenreng Rappang. PRAJA: Jurnal Ilmiah Pemerintahan, 7(3), 88-92. https://doi.org/10.51817/prj.v7i3.374 
